Article

\title{
Water Collection and Distribution Systems in the Palermo Plain during the Middle Ages
}

Giusy Lofrano ${ }^{1, *}$, Maurizio Carotenuto ${ }^{2}$, Roberta Maffettone ${ }^{3}$, Pietro Todaro ${ }^{4}$, Silvia Sammataro ${ }^{5}$ and Ioannis K. Kalavrouziotis ${ }^{6}$

1 Department of Environment, Waste Divison, Salerno Province, via Mauri 61, Salerno 84129, Italy

2 Department of Chemistry and Biology, University of Salerno, via Giovanni Paolo II 132, Fisciano (SA) 84084, Italy; E-Mail: mcarotenuto@unisa.it

3 Department of Civil Engineering, University of Salerno, via Giovanni Paolo II 132, Fisciano (SA) 84084, Italy; E-Mail: rmaffettone@unisa.it

4 UNESCO IHP (International Hydrological Programme) 1 rue Miollis-Paris 75015, France; E-Mail: geo.todaro@libero.it

5 Italian Alpine Club (CAI)-Sezione della Conca d'Oro di Palermo, via Nicolò Garzilli, Palermo 90141, Italy; E-Mail: salvatore.sammataro@sns-cai.it

6 School of Science and Technology, Hellenic Open University, Aristotelous 18, Patras 26335, Greece; E-Mail: ikalabro@eap.gr

* Author to whom correspondence should be addressed; E-Mail: glofrano@unisa.it; Tel.:+39-3479-060-670; Fax: +39-089-969-603.

Received: 21 August 2013; in revised form: 23 September 2013 / Accepted: 26 September 2013 / Published: 14 October 2013

\begin{abstract}
It has been said that Palermo is short of available water. However, nothing could be more wrong. Well-documented Arab sources and narrative chronicles reported an abundance of groundwater resources in Palermo Plain since the Middle Ages. The scarcity of sources and surface water in the Palermo Plain, compared to the groundwater abundance, led the inhabitants to use groundwater both for irrigation and domestic usage through a complex and sustainable hydraulic system. Vertical and horizontal (qanāts) wells, conveyed water towards gardens and public fountains making the Arabic Bal'harm (Palermo) a flourishing town. When visitors walk through the streets of Palermo's historical center, among Arab ruins and Baroque architecture, they hardly imagine that there is a wide and varied cultural heritage of underground cavities hidden in the basements where water flows in intricate networks fed from a numerous springs. Only in recent years was a part of this system brought to light. Moreover, the city still has a wide
\end{abstract}


and fascinating water distribution system consisting of irrigation basin (gebbie), ingenious hydraulic machines named senie, and distribution chessboard of irrigation (saje) and drinking water (catusi) canals. The medieval water collection and distribution systems and their various components in the Palermo Plain are reviewed together with the influence of the Arab water management on environment.

Keywords: history; Palermo; qanāt; ingruttati; gebbia; senia; saje

\section{Introduction}

Contrary to what is commonly believed, Palermo is a city of water. The first Phoenician settlements of Palermo were sat between the banks of two rivers, Kemonia and Papireto which made the plan of the town looks like a flower; hence its first name was $\mathrm{Ziz}$, the flower [1]. Nowadays, the two rivers no longer flow through the city, but a walk in the streets of Palermo's historical center continues to be a fascinating journey among mysterious legends, Arab ruins, Baroque architecture and underground caves hidden in the basements where water flows in intricate networks fed by numerous springs. Well-documented Arab sources and narrative chronicles report an abundance of groundwater resources in Palermo Plain, which were exploited trough a fascinating hydraulic system [2,3]. A number of galleries (cunicoli), which use gravity to transport water captured from the water table to the surface in numerous artificial springs, characterize the subterranean layer of the plain and city of Palermo. Nevertheless, only in recent years was a part of this complex system of wells and cannels brought to light. The qanats represent the main component of this complex hydraulic system, being used both for the irrigation of agricultural lands which surrounded the city and for the water supply of certain urban districts [4].

Qanāts are gently sloping tunnels dug nearly horizontally into an alluvial fan until the water table is pierced. Once constructed, ground water filters into the channel, runs down its gentle slope, and emerges at the surface as a stream [5]. Apparently originating in pre-Achaemenid Persia, tunnel-wells spread to Egypt, the Levant, and Arabia into Achaemenid times (550-331 BCE) [5,6]. Successively, the Arabs carried qanāts across North Africa into Spain and Cyprus; they are also found in Central Asia, western China, and on a more limited scale in dry regions of Latin America [3,7,8]. As consequence of this wide diffusion, 27 titles pertaining to qanāt can be counted around the world $[3,4,9,10]$. In arid climates where erosion rates are minimal, even ancient qanāts are easily identified in aerial photos as lines of craters formed by the deposition of excavation material around vertical shafts which can reach the depth of $100 \mathrm{~m}$ and have a spacing of 20-100 $\mathrm{m}$ [11]. Their bottom is connected by a tunnel about $1 \mathrm{~m}$ wide and $2 \mathrm{~m}$ high in which water is freely flowing by gravity away from the main well (mother well) to lower and flatter agricultural lands [7]. The flow of water in qanāts is proportionate to the available supply in the aquifer and when properly maintained, these infiltration channels provide a dependable supply of water for centuries. Since a qanāt relies entirely on passive tapping of the water table by gravity, it does not upset the natural water balance, whereas the withdrawal of water by pumping can lead to aquifer depletion [2,5,12]. For this reason, they represent one of the most ecological water recovery systems available for arid regions. In many countries, these systems worked up to recent times when new technologies and governmental policies 
forced changes [8,13]. In 2001, the Iranian Ministry of Energy and Water indicated that there were roughly 33,000 small and large active qanāts in Iran, with an average annual discharge of roughly 8 billion $\mathrm{m}^{3}$ [14]. Ketthara (one of the 27 names for qanatt) continued to function for much of the northern Moroccan oasis until the early 1970s till the advent of motorized water pumping exploiting deep aquifers and the construction of dams [11].

In Italy, qanāts are mainly present in the Palermo Plain (Sicily), where they are known as ingruttati, although some similar ones are being found in the Campania Region [15].

The present paper was inspired by a visit to the ingruttati of Palermo, which was followed by a detailed research of the limited data available in literature, mainly in Italian, related to these fascinating systems.

The purpose of this work is to review the medieval water collection and distribution systems in the Palermo Plain on the base of information collected through literature studies and the experience of geologists related to Palermo Plain underground water sources, and also to study the various components of the system providing maps with layout of the city during Arab period and qanāts localization. Moreover, the paper examines the influence that the Arab water management had on its environment.

\section{Background}

\subsection{Hydrogeological Characteristics of Palermo Plain}

Hydrogeological structure of Palermo Plain is characterised by a large marine terrace of Pleistocene bio-calcarenites with a high permeability due to porosity, at the edge of which there are two chains of high hills formed by Mesozoic limestone (with a high degree of cracking) [2,4]. Thanks to the presence of a not very deep (about $100 \mathrm{~m}$ ) waterproof tertiary platform (constituted of hard clays, Numidian Flysch) with a thickness of more than thousand meters, and the high permeability of surface rocks, rainwater does not disperse in depth but accumulates as groundwater (Figure 1).

Figure 1. Geological map of the Palermo Plain. The blue circles indicate groundwater exploited in the Middle Ages: At the top, Piana dei Colli; in the middle, Mezzomonreale; at the bottom, Brancaccio-Maredolce.

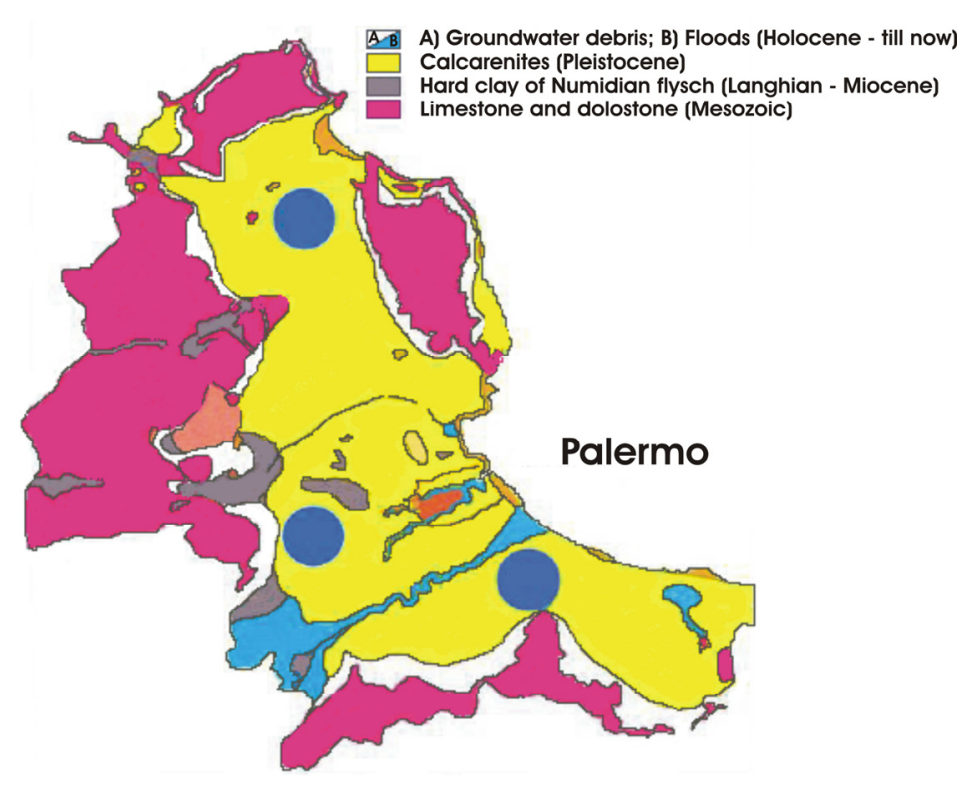


This hydrogeological feature has historically allowed the exploitation of both surface water resources (foothill sources), known since the medieval period and groundwater aquifer through the use of thousands of vertical wells (with water wheels, senie, in Arabic called sāniya) and horizontal wells called pozzi a ripiano or ingruttati (qanāts).

\subsection{Bal'harm}

The Arab conquest of Sicily began in 827 and Palermo was taken in 831 . Their empire lasted for two hundred years. During the Arab domination, Palermo was a flourishing and wealthy city with all the characteristics of a Middle Eastern city. It became one of the Mediterranean capitals with more than 300 mosques (as reported in 973 by the Iraqi geographer Ibn Hawqal) and a population of over 250,000 inhabitants, when in Rome or Milan there were no more than 20,000 or 30,000. A layout of urban expansion of Palermo during Islamic period is shown in Figure 2.

Figure 2. Layout of Palermo: historical center (purple area); urban expansion during Arab period (green area).

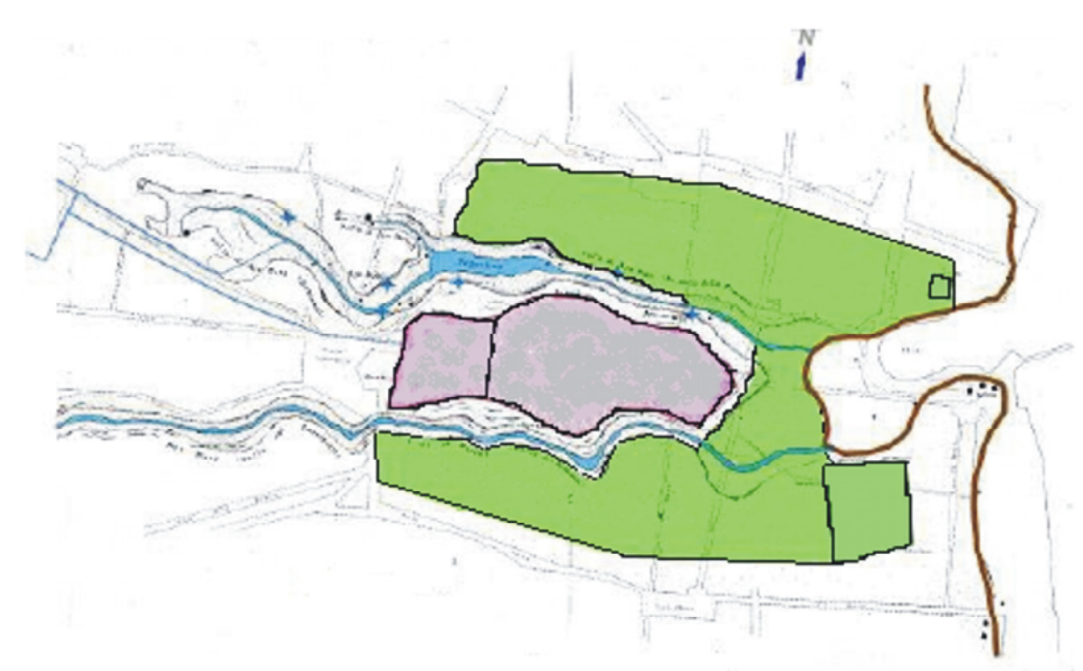

\section{Water Collection}

\subsection{Water Sources}

The great abundance subsurface aquifer compared to few points of the gushing water present in the Palermo Plain, led the native inhabitants to take advantage of groundwater for both irrigation and domestic use.

Many Arabic writers left documents on the nature and location of the sources (in Arabic called $A y n$ ), the use of water and its management and distribution for the use both in the fields around and inside the city walls where the presence of numerous orchards (nuare, in Arabic called nwar) and gardens (in Arabic called al-riy), irrigated with the waters coming from gushing springs (favara, in Arabic called fawwara), made Palermo a lush city.

According to historical iconography the main points of outcrops were those of Garbali, now called Gabriele (derived from Arabic word al-garbal, the sieve). The other known and noteworthy medieval springs are the still active Baida (in Arabic called Ayn al-Bayda) with the nearby al Gariah (the 
beautiful), the now drained Ambleri (in Arabic called Ayn billawni) placed under Monte Aricchiuta in Villagrazia, the Favara di San Ciro under Monte Grifone in Brancaccio-Maredolce where there is still the original intake structure named Three arches. Limited information is available about the springs of Sambucha (in Arabic called Ayn al-Hadid) and the nearby Garbiyya which have been hypothetically placed along the Kemonia valley, in the locality of Molara-Sambucia (in Arabic called Balhara), Ayn at Tisc (known as the source of the nine women), Qadus (catuso, conical clay pipe) hypothetically placed near the military camp (in Arabic called Mu 'Askar) and Ayn abu Malik that had to flow out near the Tower of the brave (in Arabic called Burg al Battal).

In the southern part of the plain, at the foot of Monte Grifone, there gushed two springs: the Grande Favara and the Piccola Favara, the first of which had a water flow greater then $50 \mathrm{~L} \cdot \mathrm{s}^{-1}$, similar to the source of Gabriele (Garbali), and fed the famous Maredolce Lake (in Arabic Al Baheira).

\subsection{Vertical Wells}

During the Middle Ages, vertical wells (in Arabic called bir) were ubiquitous in the Palermo Plain, in both the villages and inside the city walls. The wells for domestic use (Figure 3a-f) were different from those used for irrigation that had to accommodate the bulky hydraulic device of senie and thus had a rectangular shape, typically equal to 6 palms $(163 \mathrm{~cm})$ or 3 and a half palms $(92 \mathrm{~cm})$. Other vertical wells catalogued, although less common, have provided the following dimensions: $64 \mathrm{~cm} \times 90 \mathrm{~cm} ; 51 \mathrm{~cm} \times 128 \mathrm{~cm} ; 90 \mathrm{~cm} \times 150 \mathrm{~cm} ; 120 \mathrm{~cm} \times 150 \mathrm{~cm}$ (Figure 3d) [2].

The squared wells, mainly used for domestic purposes, were normally smaller in size, with sides equal to 3 palms, corresponding to $78-90 \mathrm{~cm}$. Nowadays, the geological data allow us to promptly confirm the description left by Ibn Hawqal, who visited Palermo in the 10th century. According to his diaries, the inhabitants of Cassaro (al-Qasr) (the old center of Palermo) quenched their thirst by drawing water from wells present in their own home: "the inhabitants of the old city (al-Qasr) like those of Halisah (the fortified citadel, seat of the emir) and the remaining districts, quench their thirst with water from the wells of their own homes, which light or heavy, they prefer respect to freshwater flowing nearby". People who lived outside the walls drank "the abundant waters that flow around Palermo from west to east, with force as to turn each two millstones".

\subsection{Qanāts}

\subsubsection{Qanāts' Discovery}

In the Palermo Plain, the rediscovery of qanāts is quite recent and their systematic study is made complex by the difficulties of access and exploration of many of their parts. The first qanāt discovered in Palermo (Uscibene qanāt) has been dated at the Islamic high Middle Ages but the maximum qanāts spread was achieved only after the 16th century during the Spanish period [3]. Nowadays, the mystery of their origin and the time of their introduction in Sicily continues, since similar narrow structures, used to convey water, have recently been revisited and studied in Syracuse (Nymphaeum) and Agrigento (Zuccarello) and attributed to the Greek-Corinthian period [2,4].

In 1979, during the excavation for the construction of a residential building in via Pindemonte, the geologist Pietro Todaro [2] discovered the mouths of a series of small wells which were curiously placed at 
the same distance of about $20 \mathrm{~m}$ from each other, connected by a high tunnel in which water flowed. Until that time, these galleries were considered as "Beati Paoli passages", escape routes for the imaginary "men of honor" of the Luigi Natoli novel. This qanāt was later identified as Gesuitico Basso alla Vignicella.

Figure 3. Mouths of vertical shafts catalogued in Palermo: (a) squared mouth of the well in via delle Balate (Albergheria); (b) rectangular mouth of the well in Vicolo Massi dell'Albergheria; (c) squared mouth of the well in via Mongitore (Albergheria); (d) squared mouth of the well in via Elia; (e) circular mouth of the well in via delle Balate (Albergheria); (f) squared mouth of the well in the Archbishop's Palace.

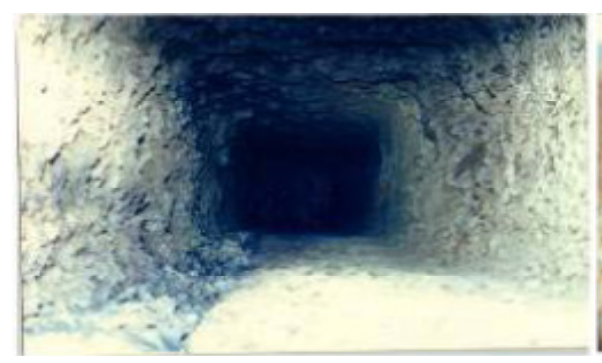

(a)

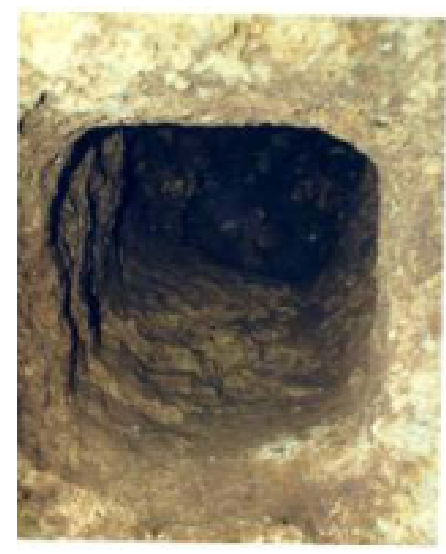

(c)

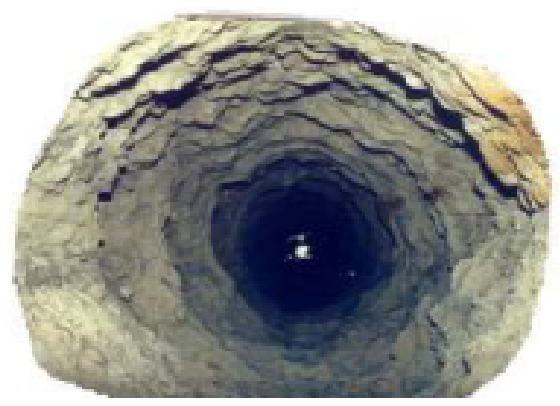

(e)

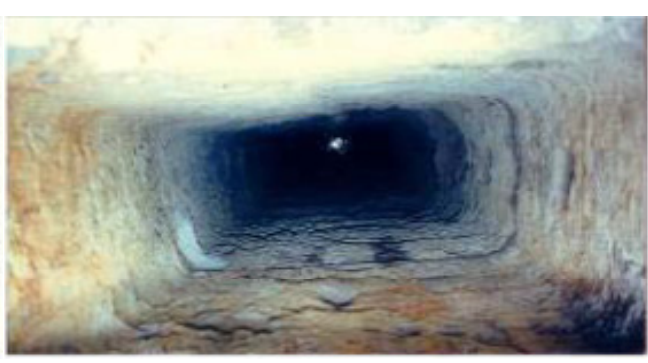

(b)

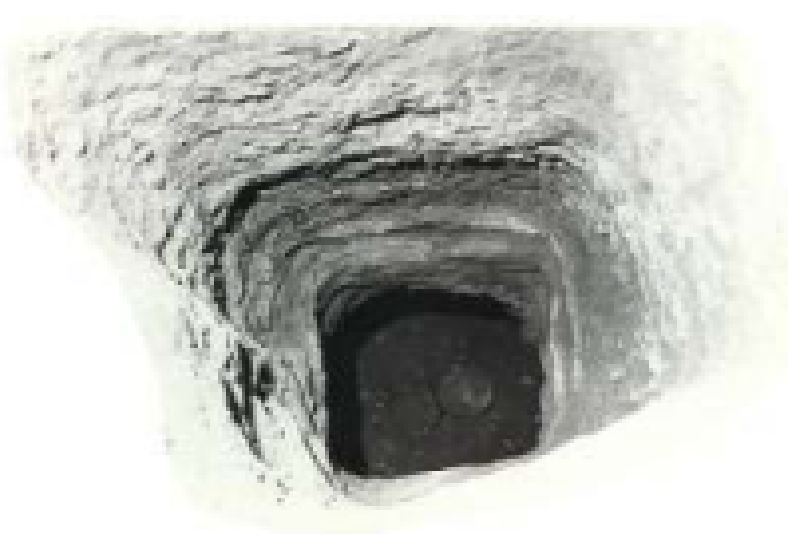

(d)

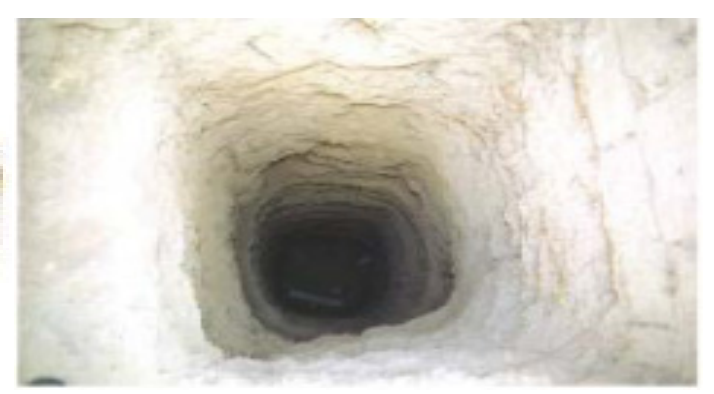

(f)

Palermo's qanāts have had a continuity of use for centuries. In 1525, the city still received water from Uscibene which is considered the oldest qanāt and paid fees for its maintenance. The latest digging of the qanāt seems to date from the 16th century (Gesuitico Alto) but, even at the beginning of the 19th century, a particularly productive qanāt was built in the Palermo Plain at Cruillas (Amato-Bova of Villa Trabia) [4]. 
Nowadays, 25 qanāts located in the hydrological basin of the Palermo Plain have been identified, as shown in Figure 4, together with five surface channels, two of which fed from the Gabriele's headwaters. Unfortunately, efforts to open the whole qanats system have not been successful; only three qanāts can be visited in Palermo: Gesuitico Basso, Gesuitico Alto and Uscibene, but the existence of such passages reminds us that many of Bal'harm's secrets are yet to be revealed.

Figure 4. List of 25 qanāts together with 5 surface canals located in the hydrological basin of the Palermo Plain (adopted from Todaro [2]). Dashed lines: The paths are only indicative and hypothesized, unexplored and unrecognized. Purple lines: Historical irrigation canals of Mezzomonreale Plain. Blue light lines: Water supply system (incatusato).

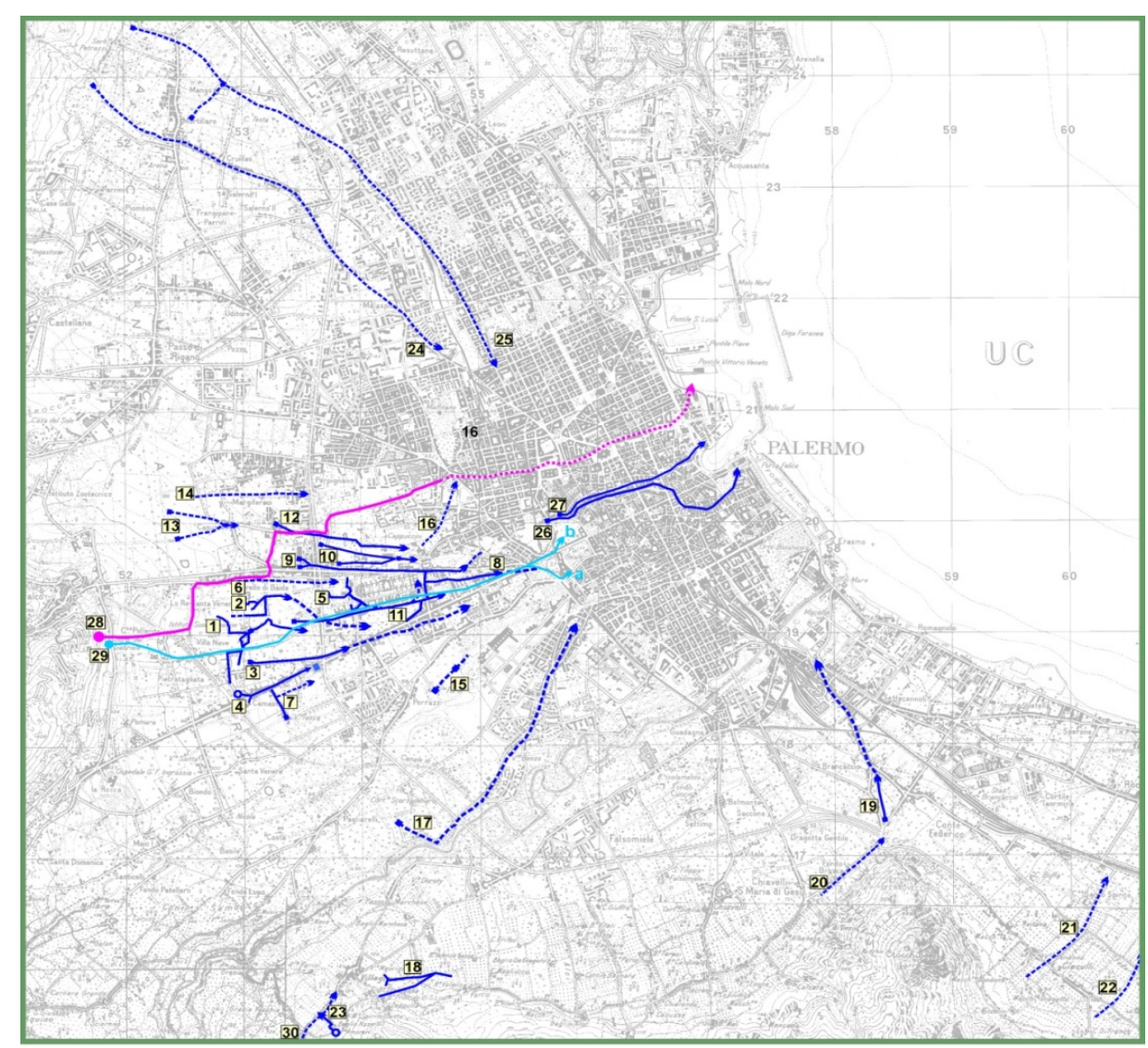

Notes: (1) Gesuitico Alto in Case Miciulla; (2) Scibene; (3) Qanāt in Pietratagliata-Calatafimi street; (4) Airoldi; (5) Acqua Nuova in Beninati (or Gesuitico Basso); (6) Bova in Altarello di Baida street; (7) Florio-Trasselli; (8) Santonocito and Calafiore; (9) Danisinni; (10) La Rosa at Cappuccini; (11) Tornabene; (12) Siccheria; (13) Scozzari in Casuzze; (14) Daniele in Margifaraci; (15) Wells with joint tunnels in Fossa della Garofala;

(16) Qanāt at Olivella; (17) Ciaccio-Martinez at Porcelli; (18) Maurigi in Villagrazia; (19) Maredolce; (20) Furieri drainage tunnel in Brasca street; (21) Bonanno in Ciaculli; (22) Floridia-Urso; (23) Passiaturi of Ambleri; (24) Blando-Parisi of Villa Isnello; (25) Amato-Bova of Villa Trabia; (26) Papireto-Dogana; (27) Papireto-Castello; (28) Gabriele (irrigation channel); (29) Gabriele (incatusato) (drinking water); (30) Migliore (former S. Chiara) in Villagrazia.

\subsubsection{Technical Features}

The main technical feature, which characterizes some of Palermo's qanāts as distinct from the oldest Middle Eastern examples, is the lack of a main water supply (mother well), which is often integrated by a 
wide cross-drainage tunnel located upstream [2]. This innovative feature confirms the significant evolution of the principles and techniques reached in Sicily in the construction of aqueducts.

Once the water table had been identified and the route of the qanāt established, the excavation advanced upstream in order to meet the wet strata only in the vicinity of the water table. The correct direction of excavation was assured in a very simple manner, using three lamps placed along the bed of the channel that served both to illuminate the environment and to keep the desired alignment until the completion of the tunnel [2]. Along the ingruttati journey, access to water was possible via wells which are located at a regular distance $(20 \mathrm{~m})$ one from another and were used during the excavation to extract dug out material and served for ventilation.

Qanāts were excavated by a class of professional diggers called puzzari, highly esteemed and paid for their long-lasting and dangerous work: more than 10 years were required for the completion of even a short (a few km long) qanāt, and a high death toll was not unusual, due to flashing water or tunnel collapse. Since the soil was friable, the tools of the puzzari were only a broad-bladed pick, a shovel and a small oil lamp or a torch. Therefore, the vaulted walls of qanats were often blackened by the smoke [4]. When the flame faded due to the lack of oxygen, puzzari knew that had to leave the tunnel and dig another vertical shaft to provide more air. Where the qanät's tunnels were very deep and ventilation was particularly poor, vertical shafts were dug on either side of the tunnel [2]. A fire was lit to make the stale air rise up one shaft and draw fresh air down the other [4]. Figure 5 shows the hydrological model of the ingruttati.

Figure 5. Hydrogeological model of Gesuitico Alto qanāt: 1, main and secondary drainage tunnels; 2, collector channel; 3, mother well; 4, vertical shafts; 5, flow direction; 6 , water table level in the limestone formation; 7, substrate supply; 8, qanāt mounth; 9, collecting tank; 10, senia; 11, irrigation tank (gebbia); 12, irrigation chanals (saje); 13, terracotta conduct; 14, distribution water tower (castelletto); 15, drinking water (catusi conducts).

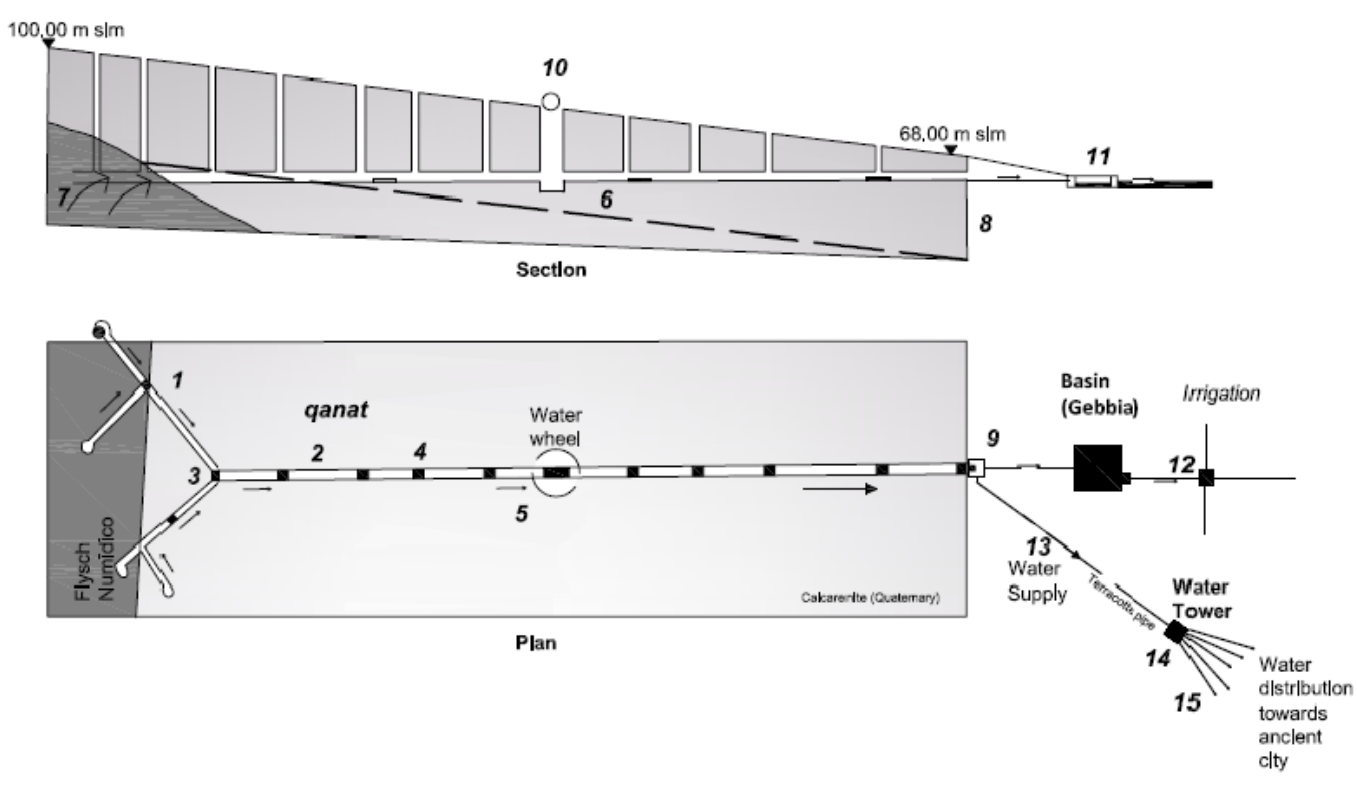

Nowadays, because of the intensive activities surrounding the qanāts as well as the leaching of wastewater pits, the water from the qanāts is no longer drinkable but it continues to be drawn for irrigation in the Palermo Plain. 
The spread of qanäts is associated with the construction of other underground structures such as Scirocco Chambers, vaulted and well-ventilated underground rooms, where people could shelter away from the burning heat and oppressive sultriness that prevails when the Scirocco wind blows in from Africa. The suggestive name of Scirocco Chamber, used to indicate these characteristic environments was used for the first time in a deed dated 5 August, 1691, where a cave was described with a fountain in the middle and coated with the ceramics of Valencia. The place was the famous Villa of the Four Rooms (Villa delle Quattro Camere) of the Duke of Terranova, located near the Capuchin Monastery in Siccheria, of which today only the name remains. The qanāt of Siccheria, with its fresh waters, goes through the Scirocco Chamber permitting a cooling, passive effect.

\subsubsection{Characteristics of Some qanāts in Palermo Plain}

The outlet flow rate as well as the length of a qanāt can vary significantly [16] and in most of Palermo's qanāts they have not yet been measured. The Palermo's qanāts generally run over approximately a kilometer, but they may be as long as $2 \mathrm{~km}$.

The Cruillas qanāt was one of the most productive qanāts in the plain. It was built at the beginning of the 19th century and reached the length of about $2 \mathrm{~km}$, providing at the surface from two to five zappe (hoes water) corresponding to $26 / 65 \mathrm{~L} \cdot \mathrm{s}^{-1}$, in relation to the season. In the past, the hoe (zappa) was the unit measurement of flow rate in Sicily. It has been estimated that one hoe corresponded to the amount of water that overflows from a pipe of about $10.5 \mathrm{~cm}$ with pressure provided by a water level of a palm $(25.971 \mathrm{~cm})$ above the axis of the pipe, corresponding to $63 \mathrm{~m}^{3} \mathrm{~h}^{-1}$ [17].

The flow rate of Castelforte qanāt in Piana dei Colli, about $1.4 \mathrm{~km}$ length, was much smaller than Cruillas, in fact, during the summer it provided a flow rate of $1 / 2$ hoe $\left(6.5 \mathrm{~L} \cdot \mathrm{s}^{-1}\right)$. The Maurigi qanāt in Villagrazia, recently rediscovered by the Italian Alpine Club (CAI), branched into four levels, reaching a maximum depth of $20 \mathrm{~m}$ with an over $1.5 \mathrm{~km}$ length. In 1885, this qanāt provided a capacity of $6.8 \mathrm{~L} \cdot \mathrm{s}^{-1}$, which were used both for drinking water (southern network of small castles) and irrigation. Today, its flow rate is reduced to less than $1.5 \mathrm{~L} \cdot \mathrm{s}^{-1}$. During 1551 , the Senate of Palermo ordered the measurement of the flow rate of Uscibene qanāt and it proved to be $8.5 \mathrm{~L} \cdot \mathrm{s}^{-1}$. On March 2003, at the outlet section of the Scirocco Chamber of Villa Savagnone, the flow rate was reduced to about $1 \mathrm{~L} \cdot \mathrm{s}^{-1}$.

The Gesuitico Basso presents a variable height, with a minimum of $1.5 \mathrm{~m}$, while the width is around $80 \mathrm{~cm}$. The water temperature is about $10^{\circ} \mathrm{C}$. The Gesuitico Alto is located in the Micciudda (Altarello di Baida), it was commissioned in the 15th century by Gerardo Alliata, Knight of Malta [2]. Figure 6a shows the entry point of Gesuitico Alto. The qanät continues to be fed by a flurry of springs which are shown in Figure 6b. The average height of Gesuitico Alto is $2.5 \mathrm{~m}$, while the width is $60-70 \mathrm{~cm}$. The section of the channel is partially flooded up to a maximum height of $40 \mathrm{~cm}$. Some stretches of the qanāt are characterised by yellowish bio-calcarenites walls (Figure 6c). When the tunnel passed through an area of soft sand, bricks of clay or autochthonous materials excavated from the tunnels were inserted into the tunnel to prevent collapse. Some stretches of Gesuitico Alto qanāt present a gabled roof and walls covered by these bricks (Figure 6d,e). Nowadays, all the vertical shafts are completely covered by urban settlement, but their underground mouths are well preserved. Figure $6 \mathrm{f}$ shows a circular section of vertical shafts found along the hypogeum. 
Figure 6. Gesuitico Alto qanāt: (a) entry point; (b) spring feding the qanāt; (c) limestone walls; (d) gabled roof tunnel with walls covered by limestone bricks; (e) clay brick arch; (f) mouth of vertical shaft; (g) step shaped shelves.

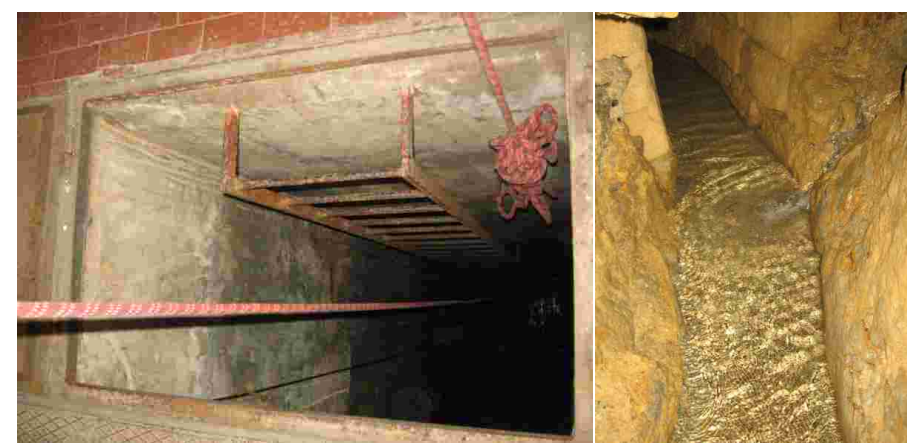

(a)

(b)

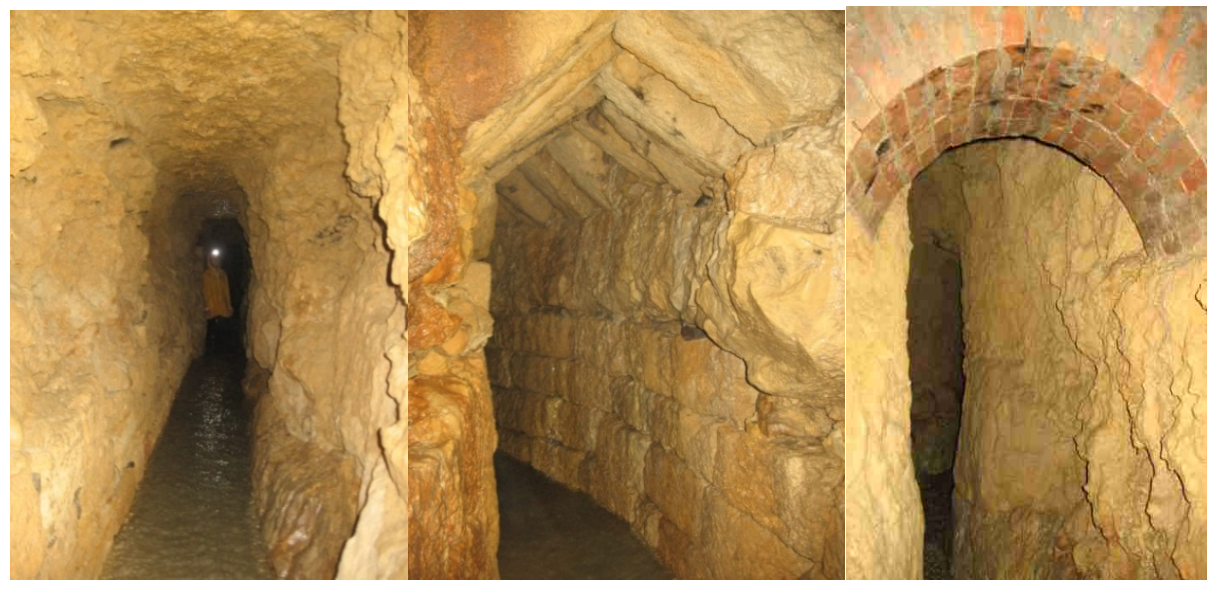

(c)

(d)

(e)

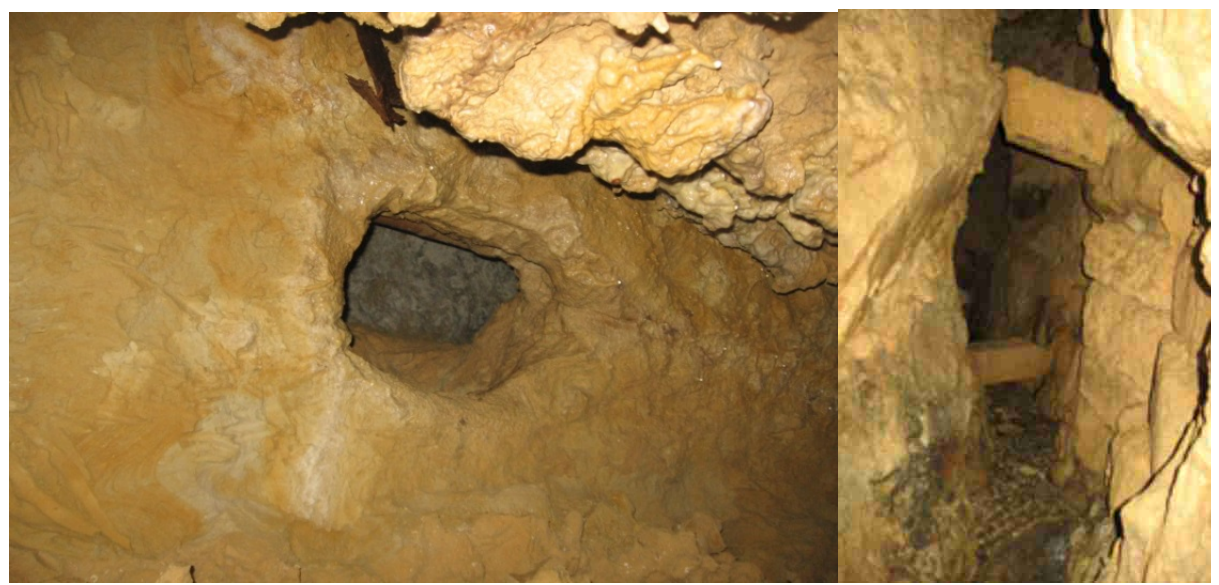

(f)

(g)

The dimensions of the galleries were established according to their use [4]. The tunnels serving to research the water table (average height $1.70 \mathrm{~m}$ ) were characterized by a trapezoidal form with the narrower base down (about $30 \mathrm{~cm}$ ), to allow the progress of the foot, and wider at the top (about $60 \mathrm{~cm}$ ) to leave more space for the passage of the shoulders and for the movement of the head and arms. In the tunnels, the presence of some step-shaped shelves (Figure $6 \mathrm{~g}$ ) with a width of $15-20 \mathrm{~cm}$ can be also observed. It is believed that they were used as support for baskets (cufina) filled with excavated material, or even for the lamps, or for the provisioning during the few moments of rest. The 
flooded gallery normally presents a rectangular section, sometimes even a lozenge with the upper part a little wider than the bottom with an average height of $2.5 \mathrm{~m}$ and an average width of about $60 \mathrm{~cm}$. In the upper part of the walls, some shallow niches are located for the accommodation of lamps. They are normally located on the left side in respect to the direction of the digging progression [4].

\subsubsection{Ecological Aspects}

The presence of qanäts strongly influenced the environment of the Palermo Plain, which, in the 15th century, was called Conca D'Oro (meaning the Golden Shell or Horn of Plenty) on account of its lush citrus plantations, palm trees and olive groves. Aqueducts had existed in Sicily since Greek and Roman times, if not earlier. The Arabs, however, expanded irrigation to the extent that crops requiring more water than almonds, olives and hard wheat could be grown on a larger scale. The knowledge about the geological characteristics of different soils and the competences on a new water resources management fostered the spread of new crops in the Palermo Plain during the Arab period progression [4]. Ibn Hawqal, reported as flourishing gardens, water towers and channels were common in the whole Palermo Plain from al-Mu 'Askar to Wadi Abbas (Oreto river) in the south and Al Bayda (Baida) in the west [2]. The system of qanäts was used to feed, among others, the lush vegetation of the large Genoardo Park surrounding the palaces of the Norman Kings: the castles of the Zisa and Cuba. The historian, Ugo Falcando, who chronicled the reign of William I of Sicily was amazed by the wealth of water, vegetable gardens and orchards. In Liber de Regno Sicilie, he wrote: ubi et rotae volubilis obsequio descendentibus urceolis puteos videas exhauriri, cisternasque adiacentes impleri, et inde aquam per rivulos ad loca singola derivari (you can see the wheels turning in the wells filling the nearby tanks from which the water flows through towards individual farms). The presence of qanāts made Palermo Plain fruitful and flourishing, whereas the underground was enriched by living organisms and preserved ancient fragments of marine organisms. The animal species discovered in the Palermo's qanāts have been substantially small arthropods progression [4] most of them usually present in ancient underground caves as well as in vestibule zones of natural caves [15]. Nowadays, visiting qanāts, it is possible to see the roots of trees from the field above pass through the walls, finding favorable conditions for plant growth. The presence of fragments of marine organisms proved marine genesis of these sedimentary rocks, indicated in the geological literature like bio-calcarenites (lower Pleistocene) [4].

\section{Water Distribution}

Water distribution in the Palermo Plain was achieved through ingenious hydraulic machines named senie, irrigation basins (gebbie), distribution chessboard for irrigation (saje) and drinking water (catusi) canals, and distribution towers (castelletti).

\subsection{Senie}

Water was withdrawn using ingenious hydraulic machines named senie (in Arabic called saniya), shown in Figure 7, consisting of two wooden wheels: one was a tractor with vertical axis, connected to the rotating movement of an animal tied to a rod ( $u$ currituri), the other one was a water wheel 
withdrawing water from the bottom of the well. Water was poured with rhythmic continuity from senie into small masonry tanks, often covered with terracotta tiles, from which, through terracotta piping, it was collected in the gebbie, before being used for irrigation by means of saje.

Figure 7. (a) A characteristic senia framework; (b) A senia remains.

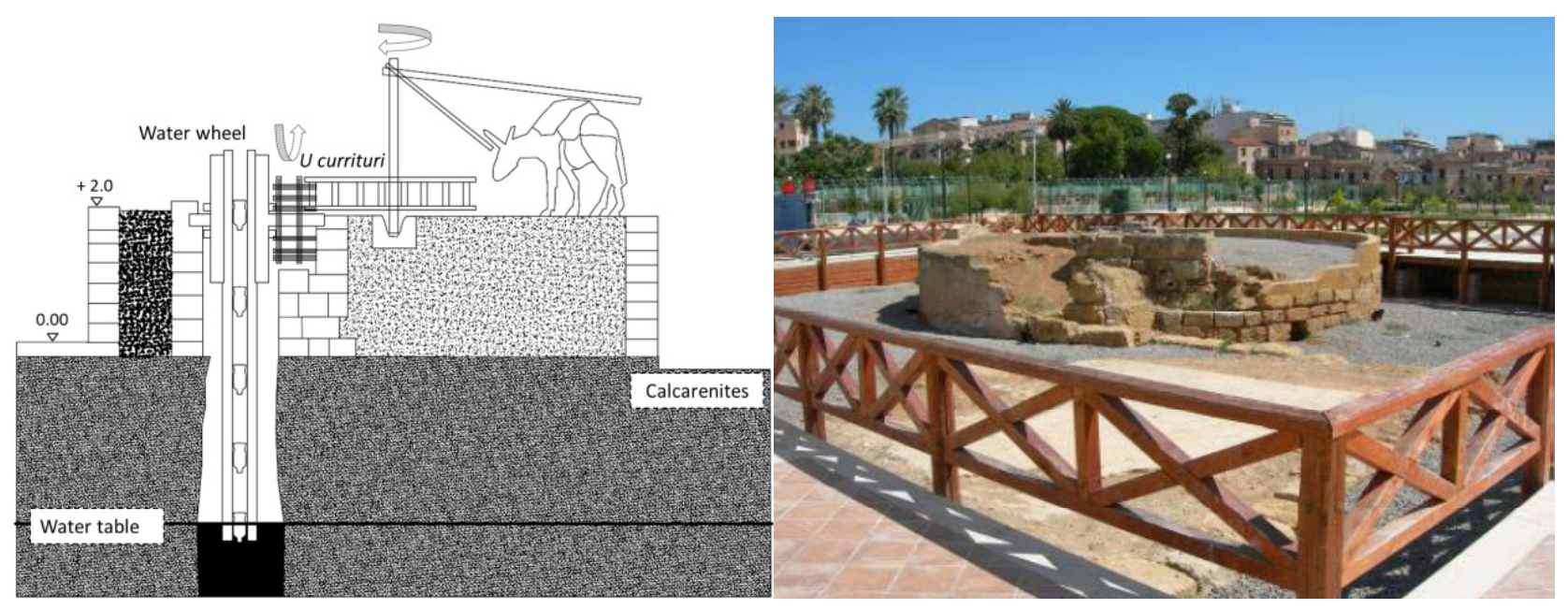

(a)

(b)

\subsection{Gebbia}

Irrigation water was stored in a low and wide stone pool, whose name, gebbia, is derived from the Arabic gabiya. Since the beginning of the last century, hundreds of these artificial basins have been recovered and catalogued in the Palermo Plain. They present variable size, depending on the extension of the land to be irrigated, a parallelepiped shape with one or more masonry columns set in the center (Figure 8). The largest one was found at Vignicella dei Gesuiti.

Figure 8. (a) A characteristic gebbia at Vignicella dei Gesuiti; (b) Diagram of the gebbia at Vignicella dei Gesuiti. (Adopted from Todaro [2]).

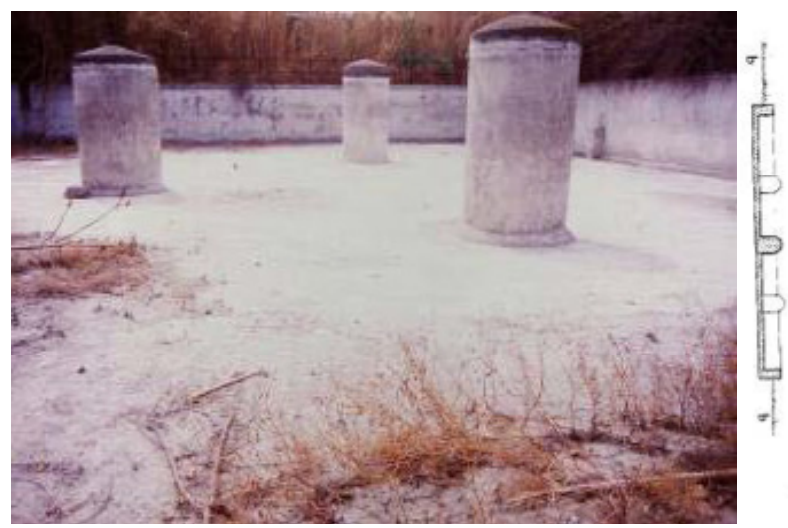

(a)

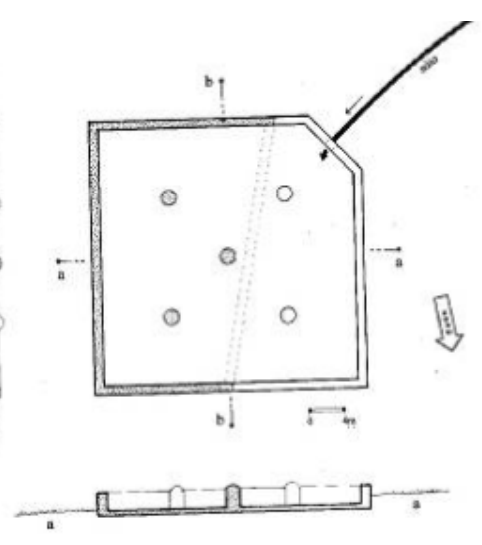

(b)

This gebbia has been partially reshaped due to some works for the construction of the ring road of the city. It consists of a square plant with a width of $28 \mathrm{~m}$ and a depth of $2 \mathrm{~m}$. On the bottom there are three large masonry pillars (originally there would have been five) with a circular section, which 
mitigated the wave action produced by the wind of Scirocco. Thanks to their presence, the dynamic thrust on the walls, which would be added to the static hydraulic one, was reduced. The topographical position of this gebbia leads to the hypothesis that it was fed by the water from the near source of the Micciulla qanāts and by the water from the nearby fishpond Scimbene, placed on the front of Palagio. The water from the gebbia was used for irrigation through a hierarchical network of ducts known as saje and furrows in the soil, known as vattali (in Arabic called batil) [2].

\subsection{Saje}

Saje from the Arabic saqiya were straight channels, masonry made or dug into the ground or the rock, the dimensions of which were variable in relation to the level of the hydraulic hierarchy. From the first level of the hierarchy, named "saya mastra", a series of secondary channels departed, which became increasingly branched and the sections of which became lower. From the gebbie, water was distributed with the saje in the gardens through their last ramifications, vattali. A similar kind of hierarchical system of saje still works in the oases of Algerian Sahara, in the central regions of Twat, and Gourara Tidikelt where traditional irrigation is carried out with the systems of foggaras [3].

\subsection{Water Towers}

Qanāts supplied drinking water to Palermo until the beginning of the last century, through a network of pipelines (incatusati, see Figure 9a,b) and distribution towers (castelletti) (Figure 9c) [4]. Some authors believe that this ingenious mechanism was developed by Arabs; some others trace it back to the roman period [1]. This last theory is confirmed both by the name of these structures: castella dividicula (distribution towers) which is of Latin origin and by the finding of analogous water distribution systems in ruins of the ancient city of Pompeii [18].

Figure 9. (a) catusi for drinking water supply; (b) saje for irrigation supply; (c) sharing water tower (castelletto) in Piazza delle Fate-Albergheria (Palermo).

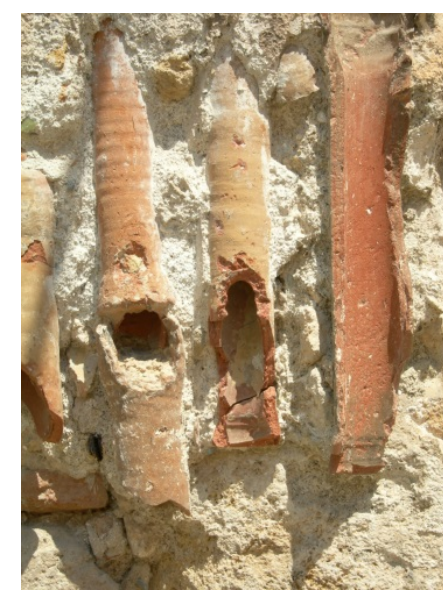

(a)

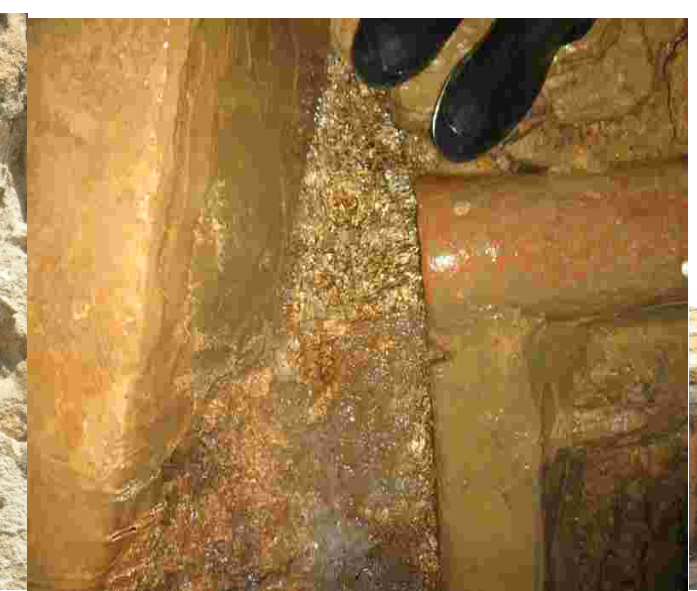

(b)

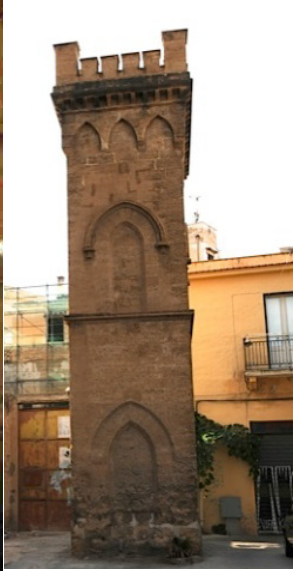

(c)

Two circuits of water towers were used for the drinking water supply of the city at the end of the 19th century. The former was fed by the headwaters of Gabriele (Campofranco-uccia) and later (1789), also by the Vignicella Gesuitica qanāt-Acqua Nuova of Benenati, which supplied the northern 
sector of the city from Altarello of Baida to Borgo Vecchio. The second circuit was fed by the waters of the Gesuitico Alto in Miciudda qanāt, which supplied the southern city from Mezzomonreale to Mandamento Kalsa. The castelletti which were brick towers up to $20 \mathrm{~m}$ high are still found scattered and incorporated into the old urban buildings of the historic city (Figure 9d), as silent witnesses of a secular hydraulic technique known as flow-through that exploited the principle of communicating vessels, constituted by fragile clay pipes catusi and incatusati [2]. The system quickly fell into disuse at the end of the 19th century with the construction of water reservoirs of S. Ciro where waters of the Scillato Spring were collected.

\section{Conclusions}

The aim of this work was to investigate the historical and morphological morphological aspects of the Palermo's water collection and distribution system during the Middle Ages. The system was mainly based on qanāts. The first qanāt discovered in Palermo (Uscibene qanāt) has been dated at the Islamic high Middle Ages but the maximum qanāts spread was achieved only after the 16th century during the Spanish period. Nowadays, three main areas supplied by qanāt systems have been identified, namely: Mezzomonreale, Piana dei Colli and Brancaccio-Maredolce, and only three qanāts can be visited in Palermo: Gesuitico Basso, Gesuitico Alto and Uscibene. Palermo's qanāts have had a continuity of use for centuries, for both irrigation of farm lands which surrounded the city and water supply of certain urban districts. Their technological features attest the significant evolution of the principles and techniques reached in Sicily in aqueduct building and maintenance. Water drawn with ingenious hydraulic machines named senie was stoked in an irrigation basin (gebbie), before being distributed via chessboard canals for irrigation (saje). Drinking water was distributed by water towers with an intricate network of catusi.

So far, traditional irrigation systems have been almost replaced by new water technologies, which often entail an over-exploitation of groundwater, exacerbating an impending water crisis. This review has been written in the belief that historical research showing the collective experience and "philosophy of water management" can provide inspiration to face future challenges.

\section{References}

1. Di Piazza, M. Palermo Città D’acqua. Aspetti Storici e Naturalistici Dell'acquedotto (in Italian); Gulotta Editore: Palermo, Italy, 2008.

2. Todaro, P. Sistemi Di Captazione e Gestione Dell'acqua Nella Piana di Palermo Nel Medioevo. In Proceedings of the International Workshop "Giardini Islamici", Palermo, Italy, 12-14 October 2006.

3. Todaro, P. Lotta Alla Desertificazione: Il progetto Foggara per il Recupero dei Sistemi Idrici Tradizionali del Sahara Algerino, Wilaya D'adrar. In Proceedings of XIII Geologists National Conference, Matera, Italy, 10-12 May 2007.

4. Lofrano, G.; Carotenuto, M.; Maffettone, R.; Todaro, P.; Sammataro, S.; Kalavrouziotis, I.K. Palermo's qanāts system: History, ecology and technology of an underground heritage. In Proceedings of the 1th IWA Workshop on Traditional Qanats Technologies, Marrakech, Morocco, 24-26 October 2013. 
5. English, P.W. The origin and spread of qanats in the old world. Proc. Am. Philos. Soc. 1968, 112, 170-181.

6. Al-Taiee, T.M. A groundwater harvesting technology in arid and semiarid regions. In Proceedings of IWA Specialized Conference on Water \& Wastewater Technologies in Ancient Civilizations, Istanbul, Turkey, 22-24 March 2012.

7. Motiee, H.; Mcbean, E.; Semsar, A.; Gharabaghi, B.; Ghomashchi, V. Assessment of the contributions of traditional qanats in sustainable water resources management. Water Resour. Dev. 2006, 22, 575-588.

8. Mostafaeipour, A. Historical background, productivity and technical issues of qanats. Water Hist. 2010, 2, 61-80.

9. Juncà Ubierna, J.A. Tunnel heritage in Spain: Roots of the underground. Tunn. Undergr. Space Technol. 1998, 13, 131-141.

10. Semsar, Y.A.; Tafti, M. An analysis of the actual situation of Qanats of Yazd city. In Proceedings of the International Conference in Qanats, Yazd, Iran, 9-22 November 2000.

11. Stiros, S.C. Accurate measurements with primitive instruments: The "paradox" in the qanat design. J. Archaeol. Sci. 2006, 33, 1058-1064.

12. Kamasch, Z. Irrigation technology, society and environment in the Roman Near East. J. Arid Environ. 2012, 86, 65-74.

13. Lightfoot, D.R. Syrian qanat Romani: History, ecology, abandonment. J. Arid Environ. 1996, 33, 321-336.

14. Mahmoudi, S. Possibility of reusing Tehran's qanats. Water Wastewater J. Iran 2001, 35, 10-12.

15. De Feo, G.; de Gisi, S.; Malvano, C.; Capolongo, D.; del Prete, S.; Manco, M.; Maurano, F.; Tropeano, E. Historical, biological and morphological aspects of the roccarainola qanāt in the district of Naples, Italy. Water Sci. Technol. Water Supply 2010, 10, 647-655.

16. Hodge, AT. Roman Aqueducts \& Water Supply, 2nd ed.; Gerald Duckworth \& Co. Ltd.: London, UK, 2002.

17. Barbera, G.; Corselli d'Ondes, G.; Ala, M.; Basile, A.; Fiammella, F. Il Giardino Della Fawarah. In Proceedings of International Workshop “Giardini Islamici”, Palermo, Italy, 12-14 October 2006.

18. Lofrano, G.; Brown, J.; de Feo, G. Water pathways through the ages: from early aqueducts to next generation of wastewater treatment plants. Adv. Water Treat. Pollut. Prev. 2012, doi:10.1007/978-94-007-4204-8_2.

(C) 2013 by the authors; licensee MDPI, Basel, Switzerland. This article is an open access article distributed under the terms and conditions of the Creative Commons Attribution license (http://creativecommons.org/licenses/by/3.0/). 